\title{
Festival Kreativitas Anak Kampung \\ Pemuda/I Kampung Prapatan Duren, Sawah, Ciputat, Tangerang Selatan
}

\author{
Yenty Rahardjo S.Sn., M.S. \\ Desain Interior, Universitas Pelita Harapan \\ yenty.rahardjo@uph.edu
}

\begin{abstract}
Festival Kreativitas Anak Kampung adalah kolaborasi antara masyarakat dan pemuda Kampung Prapatan Duren, Sawah, Ciputat, Tangerang Selatan untuk membangkitkan inovasi dan imajinasi warga terutama anak muda untuk menjadikan Kampung Prapatan lebih baik. Kegiatan ini merupakan pengabdian kepada masyarakat secara kolaboratif dan berdampak langsung kepada masyarakat melalui desain. Kegiatan dilakukan bersama mahasiswa dalam Mata Kuliah Design, Society \& Enviroment (DSE), Desain Interior, Universitas Pelita Harapan dengan metode Design Thinking, Human Center Design Process.
\end{abstract}

Kata kunci: Festival Kreatitivitas, Design, Society and Environment.

\section{PENDAHULUAN}

Kegiatan Pengabdian kepada Masyarakat memberikan kesempatan untuk belajar mengembangkan keilmuan desain dari situasi dan kondisi yang kontekstual dalam masyarakat. Pada tahun 2012, Fakultas Desain (School of Design), jurusan Desain Interior Universitas Pelita Harapan mengembangkan mata kuliah Design, Society \& Environment (selanjutnya akan disingkat menjadi DSE). Mata Kuliah ini dirancang sebagai mata kuliah yang bekerja sama dengan mahasiswa untuk melakukan kegiatan kolaboratif yang mensinergikan penelitian, tindakan (dalam bentuk pengabdian) dan desain langsung ke dalam situasi dan konteks masyarakat tertentu dengan tujuan memberikan dampak positif dan transformatif kepada semua yang terlibat.

Tahun 2016 di mata kuliah DSE, tim pelaksana PKM bersama dengan Kampung Pondok
Pucung, RT 005 dan 006, RW 02, membuat gagasan kegiatan K-aiueo. Kegiatan ini dilakukan untuk membangkitkan imajinasi dan kreativitas pemuda/i Kampung Pondok Pucung. Kegiatan ini menggunakan mural sebagai ekspresi kreativitas anak kampung.

Pada Mata Kuliah DSE tahun akademik 2016/2017, dosen dan mahasiswa bekerja sama dengan warga dan pemuda Kampung Prapatan Duren, Sawah, Ciputat, Tangerang Selatan membangkitkan inovasi dan imajinasi terutama anak mudanya untuk menjadikan Kampung Prapatan lebih baik melalui Festival Kreativitas Anak Kampung. Dan melalui kegiatan ini diharapkan dengan Design Thinking (selanjutnya akan disingkat DT), yang didampingi dengan pengabdian masyarakat akan menjadi lengkap sebagai keilmuan desain yang melayani masyarakat dan pengadian model Design, Society \& Environment (DSE). 


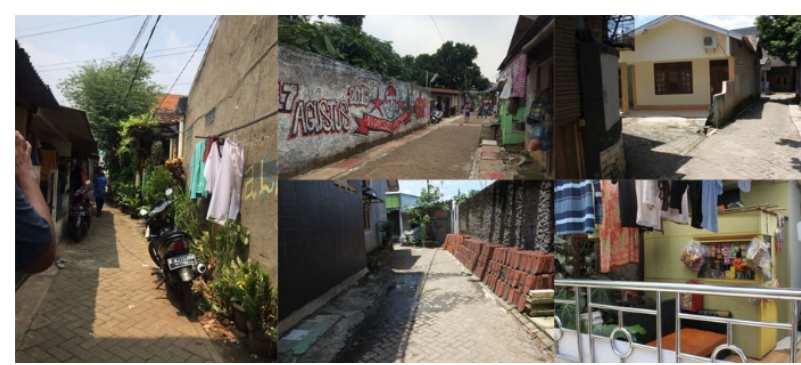

Gambar 1. Kampung Prapatan Duren Sawah Kredit: Melissa Tjioeputri

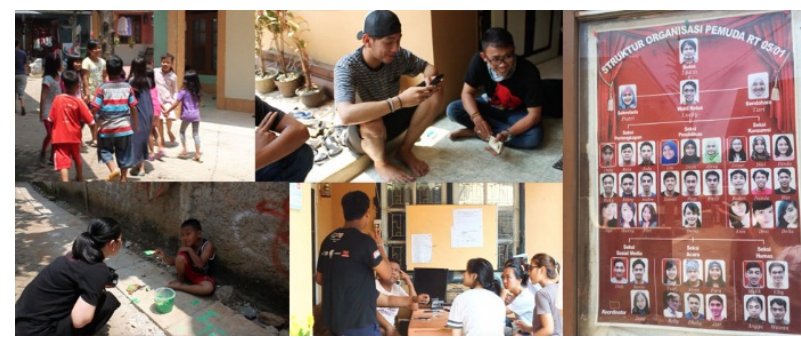

Gambar 2. Pemuda Kampung Prapatan Duren Sawah Kredit: Melissa Tjioeputri

\section{METODE}

Metode yang digunakan di Pengabdian kepada Masyarakat (selanjutnya akan disingkat PKM) ini adalah model Design, Society \& Environment (DSE) yang merupakan kombinasi Participatory Action Research dan Design Thinking, dengan prosesnya sebagai berikut:

Penelitian pendahuluan yang mengutamakan Human Center Design Process mengunakan model kombinasi Participatory Action Research (selanjutnya akan disingkat PAR) (Taggart, 2006; Crosswell, 2008; Reason and Bradburry, ed, 2001) dan Design Thinking (Brown, 2008; Brown dan Katz, 2009; Brown and Wyatt, 2010; Berg dan Lune, 2012,
Stringer, 1990; IDEO, 2013) melalui tahapan pertama: Discover Look dan Immerse in Context dengan paling kurang 8 anggota masyarakat, 3 anggota ahli, 3 situasi serupa atau inspiratif.

Tahapan kedua bersama Riung Desain adalah Ideate-Think (Brown, 2008; Brown dan Katz, 2009; Brown dan Wyat, 2010; Berg dan Lune, 2012; Stringer, 1990, IDEO, 2013) untuk perumusan masalah yang tepat. Hasil RD ini akan didiskusikan kembali bersama pemuda/I Kampung Prapatan Duren.

Tahapan ketiga adalah perancangan Prototipe Desain bersama pemuda/i Kampung Prapatan Duren, tahapan keempat adalah implemetasi desain, lalu tahap kelima adalah pelaksanaan Pre-Test, Action and Post-Test (Brown, 2008; Brown dan Katz, 2009; Brown and Wyatt, 2010; Berg dan Lune, 2012; Stringer, 1990; IDEO, 2013); Katoppo \& Sudradjat, 2015).

Proses pengukuran PreTest (Neuman, 2006; Creswell, 2008) dilihat dari kenaikan jumlah pemuda/i bahkan anak-anak yang berpartisipasi dari proses awal sampai saat pelaksanaan kegiatan, dalam PKM ini yaitu Festival Anak Kampung. Pengukuran PostTest (Neuman, 2006: Creswell, 2008) dilakukan setelah Festival Anak Kampung berlangsung, pemuda/i menunjukkan kemandirian dalam 
melakukan kegiatan secara kreatif sebagai sebuah komunitas.

\section{KEGIATAN FESTIVAL KREATIVITAS}

Tujuan dari kegiatan PKM ini adalah membangkitkan semangat dan imajinasi warga terutama anak mudanya untuk menjadikan Kampung Prapatan Duren lebih baik melalui Festival Kreativitas Anak Kampung. Tahapan kegiatan PKM dilaksanakan sebagai berikut:

Pertama, melalukan kegiatan pengumpulan data (data collecting) atau dalam model DTPAR tahapan pertama Discover-Look dengan 8 anggota komunitas yaitu 8 pemuda anggota organisasi anak muda Kampung Prapatan Duren dan Pengurus RT 005, RW 01. Dari mereka didapatkan situasi kampung dan peran aktif anak muda mengerakkan warga. Perbincangan dengan anggota ahli dilakukan dengan Agus Setiawan sebagai Pakar Tanaman, Anang Arifin sebagai Konsulatan Pemberdaya Masyarakat, Pengerak dan Adin Mbuh sebagai penggerak komunitas kampung di Semarang dan Direktur Hysteria. Dari penelitian pendahuluan ini ditemukan cara cara menggerakan suatu komunitas terutama anak muda sebagai penentu.

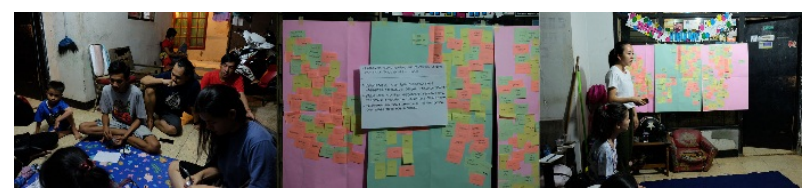

Gambar 3. Data Collecting
Kredit: Melissa Tjioeputri

Tahapan pertama Immerse in Context dengan meneliti 3 tampat sesuai dengan target penelitian: Kampung Pondok Pucung, Tangerang Selatan; Kampung Banjarsari, Cilandak, Jakarta Selatan dan Gang Cantik Kampung Sawah, Tangerang Selatan. Analogus Research yang merupakan belajar dari hal-hal yang kontras untuk membuka wawasan, adalah salon perawatan wajah, permainan Harvest Moon dan Kantin Kejujuran. Dari situasi-situasi ini dipelajari bagaimana komunitas merawat dan menumbuhkan sense of belonging.

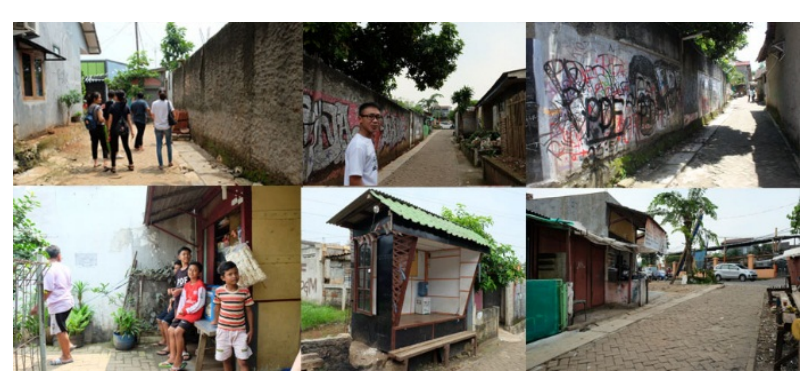

Gambar 4. Perumusan Masalah Kredit: Melissa Tjioeputri

Tahapan kedua yaitu Ideate and Think adalah menentukan tema, membuat konsep dan merumuskan permasalahan melalui pengajuan pertanyaan 'Bagaimana kita bisa..' (How Might We...?). Rumusan masalah yang dihasilkan adalah bagaimana pemuda/i Kampung Duren Prapatan membangun kebersamaan (sense of belonging) terhadap Kampung Prapatan dan kami bisa mewadahi aktivitas warga dengan 
keterbatasan lahan secara kreatif dan kolaboratif.

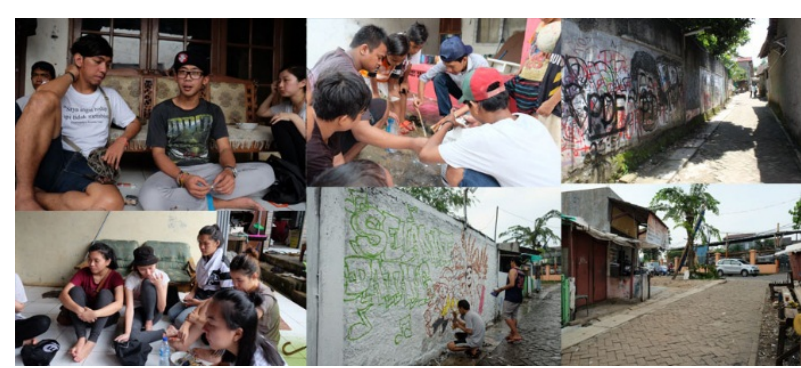

Gambar 5. Diskusi Pemuda Kampung Prapatan Duren Sawah Kredit: Melissa Tjioeputri

Tahapan ketiga yaitu Perancangan Prototipe Desain berdasarkan perumusan masalah dan mencari umpan balik (feedback) prototipe dari warga Kampung Prapatan Duren (DT-PAR fase Prototype-Act) yang hasilnya adalah prototipe sistem atau model penataan kampung secara kreatif dan kolaboratif untuk warga Kampung Prapatan Duren, melalui festival yang disebut Festival Kreativitas Anak Kampung Prapatan Duren yang digagas, dilakukan dan dirasakan hasilnya oleh anak - anak muda kampung secara mandiri dan kolaboratif bersama warga. Keempat, tahap action atau implementasi prototipe ke warga Kampung Prapatan Duren sepanjang 3 bulan, berkenalan dan melakukan pemetaan aktivitas warga bersama anak - anak mudanya, melalukan diskusi dan mendorong terjadinya perencanaan dan pelaksaaan aktivitas kreatif yang difokuskan dengan kegiatan membuat mural kampung bersama anak anak Kampung Duren Prapatan.

Kelima, bersamaan dengan itu proses pengukuran Pre-Test dilakukan dengan mencari umpan balik (feedback) warga yang dilakukan sebelum dan setelah intervensi. Kegiatan menunjukkan kemandirian dan imajinasi yang luar biasa kreatif dari anak-anak muda Kampung Prapatan Duren. Semua ide pelaksanaan hingga rancangan gambar mural, pengumpulan dana untuk melaksanakan, bahkan pengadaan cat dan perlengkapan, perencanaan acara festival, mengajak warga untuk aktif berkolaborasi dan meminta izin untuk mengecat tembok-tembok rumah dilakukan secara mandiri oleh anak-anak muda Kampung Prapatan Duren. Tim peneliti dalam hal ini hanya menjadi pemantik ide dan fasilitator dan belajar berkolaborasi bersama warga.

Proses pengukuran Post-Test dilakukan di awal tahun 2018 dengan mengunjungi kembali Kampung Duren Prapatan dan melihat penataan kampung secara kreatif terus dilakukan oleh pemuda/I Kampung Duren Prapatan melalui mural di tembok-tembok kampung. 


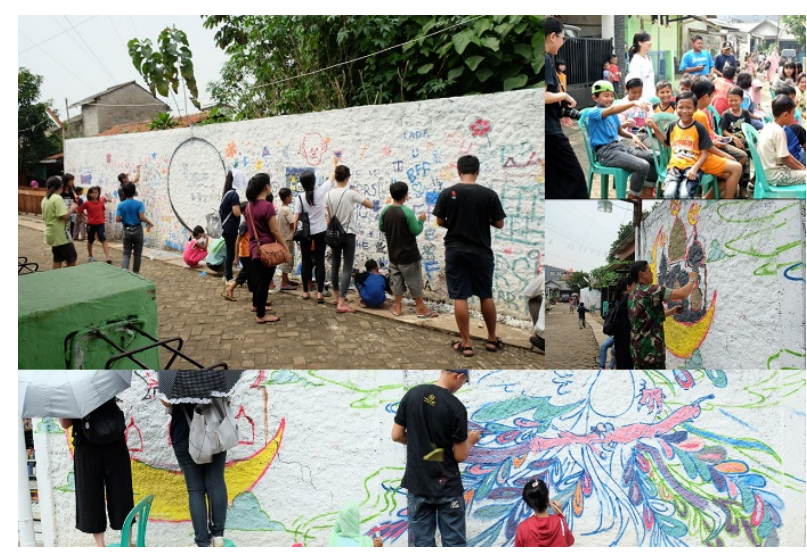

Gambar 6. Festival Kreativitas Anak Kampung Prapatan Kredit: Melissa Tjioeputri

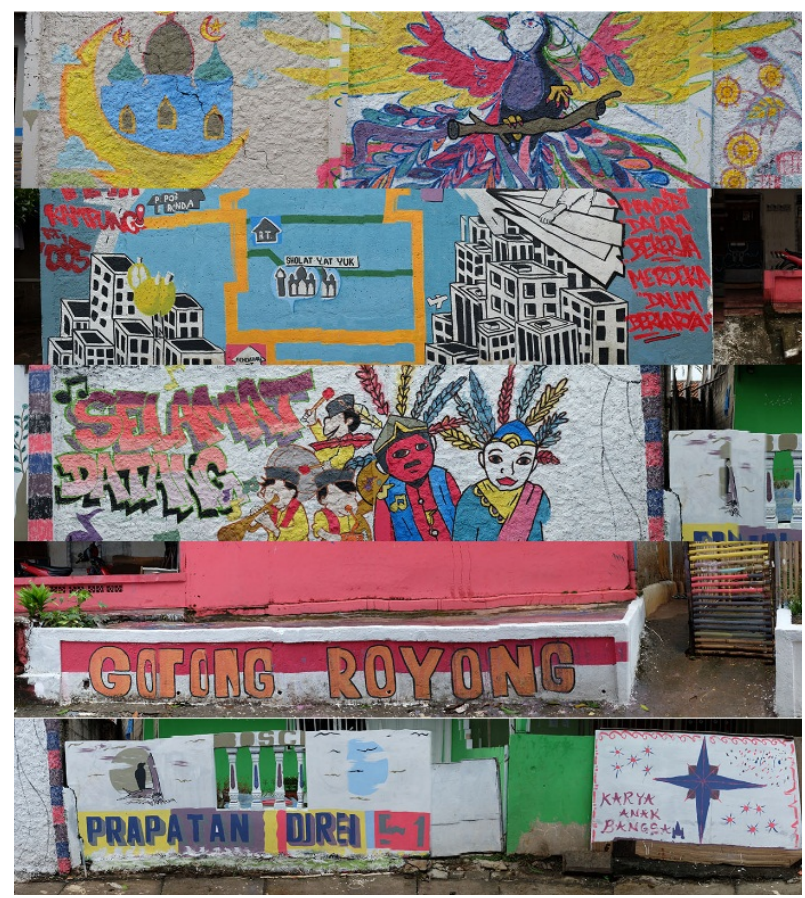

Gambar 7. Mural Festival Kreativitas Anak Kampung Prapatan Kredit: Melissa Tjioeputri

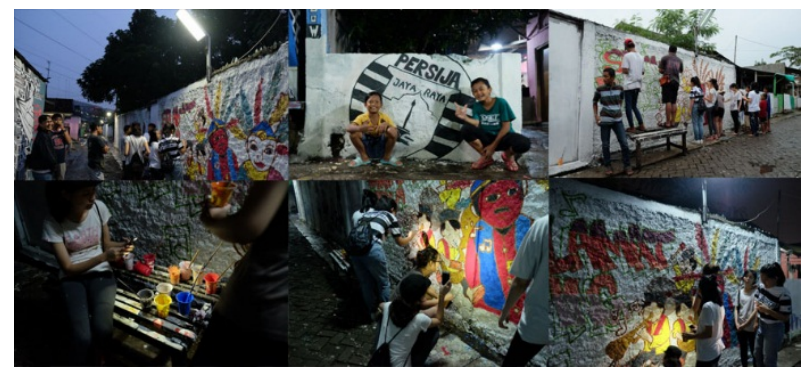

Gambar 8. Festival Kreativitas Anak Kampung Prapatan Kredit: Melissa Tjioeputri

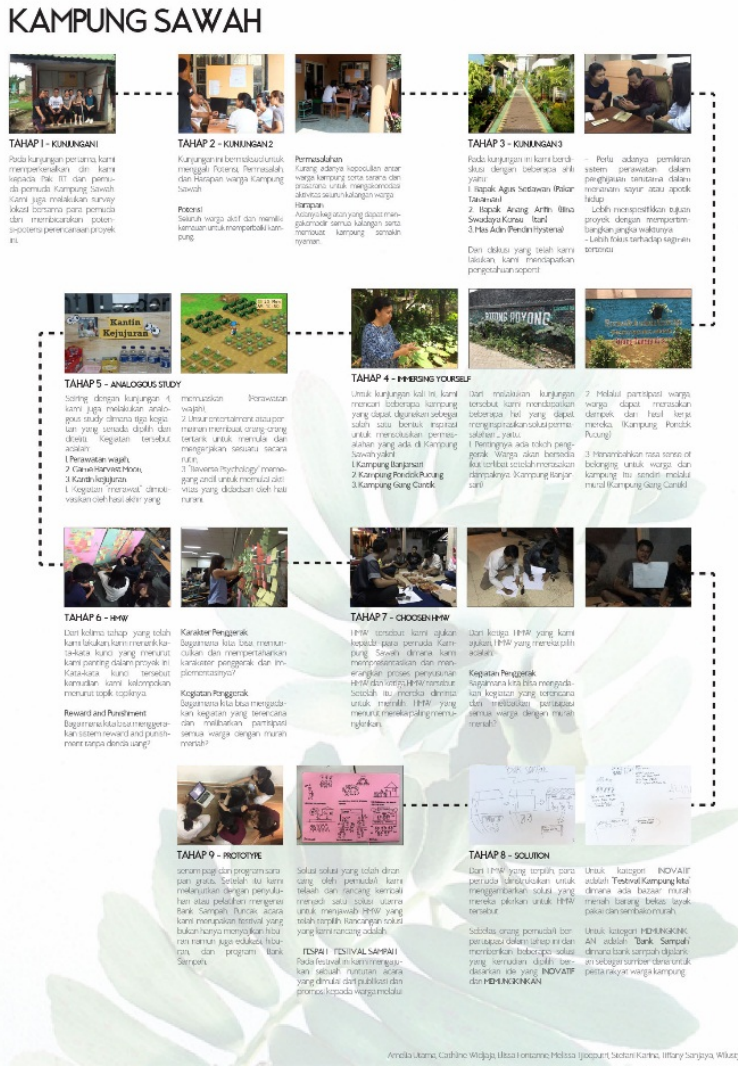

Tabel 1. Tahap Pertama PAR-DT

Kredit: Melissa Tjioeputri
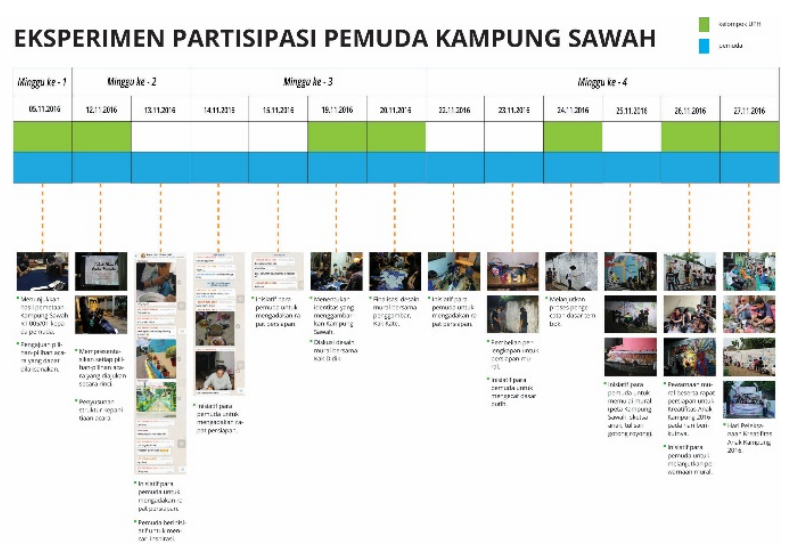

Tabel 2: Eksperimen Partisipasi Pemuda Kampung Sawah Sumber: Melissa Tjioeputri 


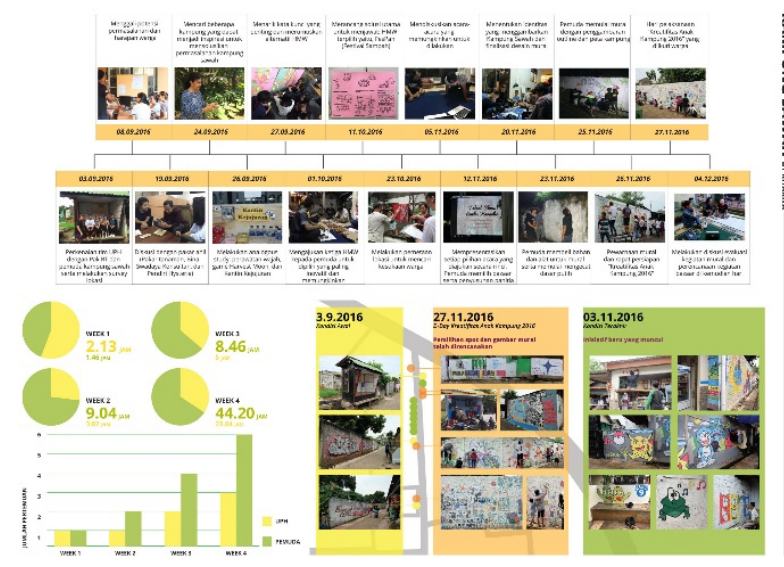

Tabel 3: Hasil Partisipasi Pemuda Kampung Sawah Sumber: Melissa Tjioeputri

\section{SIMPULAN}

Kreativitas muncul dari bagaimana sebuah komunitas menyelesaikan tugas dan aktivitas sehari-hari yang membutuhkan bukan saja individu tetapi juga konteks sosial (Sawyer, 2006). Kreativitas keseharian muncul karena kebersamaan dan improvisasi melalui proses tanpa harus begitu cermat dalam perencanaan (Sawyer, 2006). Dalam kegiatan PKM ini, ditemukan bahwa Kampung Prapatan Duren yang memiliki organisasi pemuda yang kreatif dengan dukungan dari komunitas menelurkan gagasan dan aksi untuk memajukan kampung sebagai sebuah komunitas.

Sejak awal kegiatan Pengabdian kepada Masyarakat ini sudah memikirkan keberlanjutan program. Pertama, program dirancang bersama-sama, berkolaborasi dengan warga setempat, dengan organisasi pemuda/i Kampung Duren, RT 005, RW 01, dengan menggunakan pendekatan desain partisipatif. Kedua, partisipas aktif warga adalah syarat utama pelaksanaan kegiatan, baik dalam bentuk tenaga, pemikiran, konsumsi hingga dana. Ketiga, secara khusus program ini dirancang sebagai pemantik untuk terus berlanjut dalam bentuk-bentuk kegiatan yang sama (Festival Kreatif Anak Kampung selanjutnya) atau bentuk lainnya seperti kegiatan Pasar Malam atau perayaan hari besar.

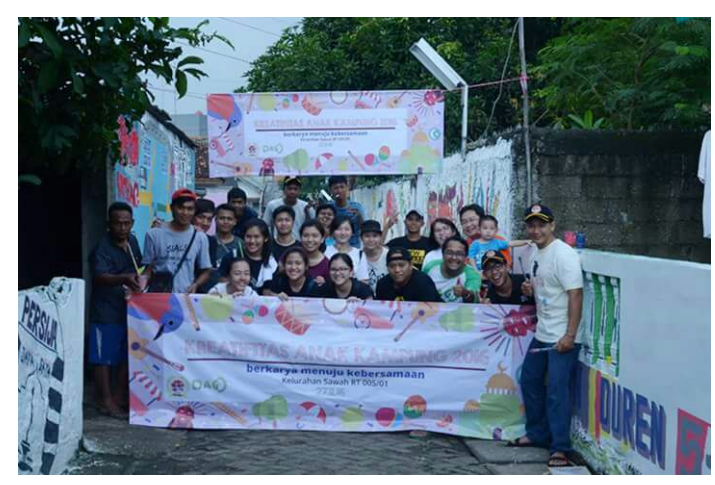

Gambar 9. Festival Kreativitas Anak Kampung Prapatan Kredit: Melissa Tjioeputri

\section{UCAPAN TERIMA KASIH}

Ucapan terima kasih diberikan kepada Universitas Pelita Harapan, Lembaga Penelitian dan Pengabdian Masyarakat (LPPM) Universitas Pelita Harapan dan kepada ketua tim Pengabdian kepada Masyarakat dan pencetus Design, Society \& Environment, Dr.Martin Lukman Katoppo, kepada mahasiswa Desain Interior yang terlibat dalam kegiatan dan penelitian Festival Kreativitas Kampung Prapatan Duren. 


\section{DAFTAR PUSTAKA}

Berg, B.L., dan Lune, H.2012. Qualitative Research Methods for the Social Sciences $8^{\text {th }} E d$, United States : Pearson Education Inc.

Brown, T. 2008. Design Thinking www.unusualleading.com , Harvard Business Review: 1-9.

Brown, T. and Katz, B. 2009. Change by Design: How Design Thinking Transforms Organizations and Inpspires Innovations. New York. Harper Collins Publishers.

Brown, T. and Wyatt, J. 2010. Design Thinking for Social Innovation, Stanford Social Innovation Review. Stanford School of Business. 29-35.

IDEO. 2013. Human Centered Design (HCD) Toolkit: Design Thinking Toolkit for Social Innovation Project $2^{\text {nd }} . e d$. Licensed under The Creative Commons New York. Harper Collins Publishers.

Katoppo, M. L. and Sudradjat, I. 2015. Combining Participatory Action Research (PAR) and Design Thinking (DT) as an alternative research method in architecture, Procedia - Social and Behavioral Sciences, International Conference ARTEPOLIS Vol.5. Architecture Program, School of Architecture, Planning and Policy Development, Institut Teknologi Bandung (ITB), Indonesia, 184 c (2015), 118-125, doi:

10.1016/j.sbspro.2015.05.069

Brown, T. and Wyatt, J. 2010. Design Thinking for Social Innovation, Stanford Social Innovation Review. Stanford School of Business. 29-35.

Sawyer, R.K. 2006. Explaning Creativity, The Science of Human Innovation, Oxford University Press, 117-136. 